\author{
Martyna DominiaK, Marlena Lembicz
}

\author{
Zakład Taksonomii Roślin \\ Wydziat Biologii \\ Uniwersytet im. Adama Mickiewicza w Poznaniu \\ Umultowska 89, 61-614 Poznań \\ E-mail: martyna.dominiak@amu.edu.pl
}

\title{
SIECI GRZYBOWE - STRUKTURA, FUNKCJE I WYKORZYSTANIE PRZEZ CZŁOWIEKA
}

\section{WPROWADZENIE}

Lata 60. i 70. XX w. to czas, który istotnie wpłynął na współczesna jakość naszego życia. Zaczynając dzień od kawy, sprawdzenia poczty elektronicznej i przeglądu najświeższych informacji „w sieci”, robimy nieświadomy ukłon w kierunku wynalazku minionego wieku, który do Polski trafił $\mathrm{w}$ latach 90. Internet zrewolucjonizował nasze życie, komunikację międzyludzką i sposób przekazu informacji. Z duma mówimy o "globalnej wiosce”, sieci łączącej wszystkie punkty na Ziemi, tak jakbyśmy to my, ludzie, byli najdoskonalszymi twórcami i pomysłodawcami. Zapominamy, że zawsze o krok przed nami jest natura. Miliony lat ewolucji sprawily, że świetnie działajace sieci komunikacyjne tworza rośliny klonalne (np. DE KROON i VAN GROENENDAEL 1997, STUEFER i współaut. 2004, DOMINIAK i współaut. 2014) i organizmy prostsze oraz ciagle niedoceniane - grzyby (STAMETS 2005).

\section{GRZYBNIA - BUDOWA I JEJ ROZROST}

Szacuje się, że na świecie występuje około 1,5 miliona gatunków grzybów, $z$ czego obecnie znanych jest około 10\% (HAwKSWORTH 1991). Organizmy te występują we wszystkich strefach klimatycznych, głównie zasiedlając lądy. Charakterystyczny kapelusz, osadzony na trzonie, który występuje u wielu znanych grzybów, m.in. u borowika szlachetnego (Boletus edulis Bull.), muchomora czerwonego [Amanita muscaria (L.) Lam.] czy pieczarki łakkowej (Agaricus campestris), to owocnik, będacy jedynie niewielka częścia ciała grzyba. Właściwy organizm stanowi, zwykle podziemna, grzybnia (łac. mycelium). Powstaje ona w wyniku rozgałęziania, krzyżowania się i anastomoz (zespalania, łączenia się) strzępek. Pojedyncza wielojądrowa strzępka (łac. hypha) ma budowę typowa dla komórki eukariotycznej, posiada nitkowaty kształt i rurkowata strukturę. Otoczona jest sztywna, wielowarstwowa, półprzepuszczalna ściana zbudowana $z \quad \beta$-glukanu, chityny, białek i polifosforanów. Aż 90\% żywej strzępki to woda, na pozostałą część składaja się: białka, węglowodany, tłuszcze i sole mineralne. Prawie połowe suchej masy strzępek stanowi węgiel (główny składnik m.in. plazmy, enzymów), oprócz niego występują azot, tlen, wodór, siarka i fosfor (RUIZ-HERRERA 1991, BUJAKIEWICZ i współaut. 2007, MOORE i współaut. 2011). Wiele grzybów na powierzchni strzępek wytwarza kryształy kwasu szczawiowego. Kwas szczawiowy, reagując $z$ różnymi minerałami, tworzy szczawiany, $\mathrm{np}$. $\mathrm{w}$ połączeniu $\mathrm{z}$ wapniem powstaja kryształy szczawianu wapnia. Krystalizacja minerałów może być zwiazana $z$ regulacja stężeń jonów pierwiastków w obrębie grzybni (WhITNEY 1989). W strzępkach grzybów (z wyjątkiem Mucoromycotina) sa ściany poprzeczne, czyli septy, które dziela grzybnię na fragmenty. Dzięki temu strzępka, będąca pojedyncza, rozgałęziona komórka, posiada mechanizmy pewnej izolacji segmentów (np. poprzez ciałka Woronina). Przemieszczanie się cytoplazmy wraz $z$ organellami (jądrami, mitochondriami, rybosomami) jest możliwe dzięki występowaniu w septach specjalnych 
otworów, porów. To zapewnia łączność protoplastu wegetatywnej grzybni, jednocześnie wyróżniając grzyby spośród innych organizmów (RUIZ-HERRERA 1991, BUJAKIEWICZ i współaut. 2007, MoORE i współaut. 2011).

Przez lata w mykologii powtarzano twierdzenie mówiące, że strzępki wydłużają się wyłącznie w części szczytowej (wzrost apikalny) (CHRISTENSEN i współaut. 2008). Następnie rozgałęziaja się, co umożliwia grzybni penetrację heterogenicznego środowiska w poszukiwaniu fragmentów bogatych w zasoby. Co dzieje się w przypadku, gdy pojawi się bariera uniemożliwiajaca chwilowe wydłużanie się strzępek w danym rejonie? Obserwacje rosnacych międzykomórkowo endofitów Epichloë i Neotyphodium pokazały, że mechanizm wzrostu może być bardziej złożony (CHRISTENSEN i współaut. 2008). Zaproponowano nowy model wzrostu - wzrost interkalarny. Zachodzi on poprzez miejscowe zwiększenie średnicy strzępki, gdzie następnie dochodzi do rozciągnięcia i wydłużenia włókien, więc w efekcie wzrasta długość strzępki (CHRISTENSEN i współaut. 2008). Dzięki temu, w miejscach o ograniczonej możliwości przesuwania się, strzępka nadal rośnie, a w dogodnym momencie wydłuża się, tym samym zajmując wolna przestrzeń. Poza tym, nowe modele kolonizacji endofitów $z$ rodziny Clavicipitaceae pokazały, że dzięki zwiększaniu średnicy strzępki, grzyb rośnie synchronicznie $z$ gospodarzem, więc nie ma trudności $z$ jego kolonizacja (CHRISTENSEN i współaut. 2008). Strzępki Epichloë i Neotyphodium preferuja charakterystyczne ustawienie równoległe do osi podłużnej liści (Ryc. 1). W zwiazku $\mathrm{z}$ tym pojawiły się wat-

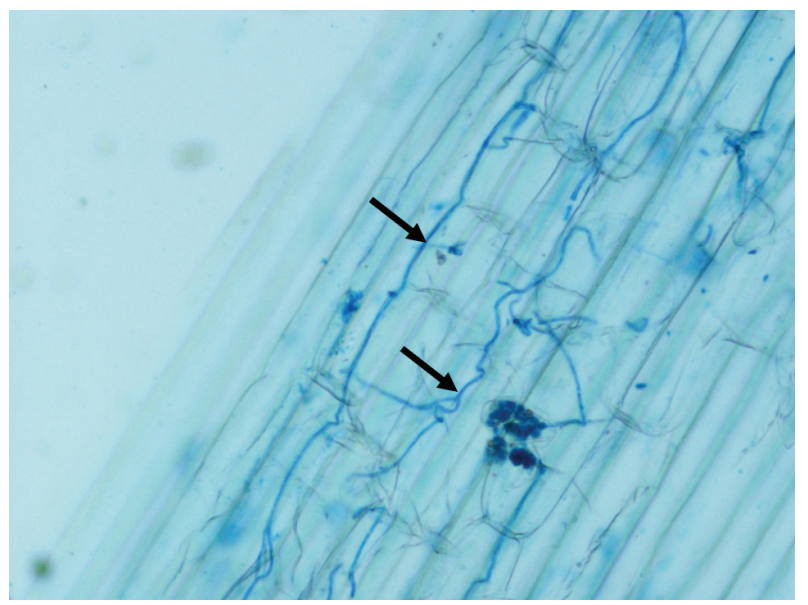

Ryc. 1. Strzępki Epichloë typhina rosnace wzdłuż osi podłużnej liści mannicy odstającej Puccinellia distans (fot. K. Górzyńska).

Strzępki te występują w przestrzeniach międzykomórkowych w nadziemnych częściach rośliny. pliwości dotyczące tego, jak grzyb radzi sobie z kolonizacją, pnac się w górę rośliny bez pomocy, np. w postaci przytwierdzania się do ścian komórkowych gospodarza. $Z$ jednej strony, brak przytwierdzania się umożliwiłby nieustanne przesuwanie się wzdłuż komórek liści, a więc również nieustanny rozwój i kolonizację. $Z$ drugiej, powstajace rozgałęzienia boczne, penetrujace między komórki gospodarza, radza sobie $z$ ciagłym przesuwaniem się ku górze wraz $z$ rozwijającymi się tkankami liści. Jak to możliwe? W rosnącym liściu traw wystepuja dwie charakterystyczne strefy: merystematyczna i ekspansji. Badania pokazały, że w strefie ekspansji strzępki grzyba przytwierdzaja się do ścian komórek gospodarza. W tym celu rozciagaja się lub spłaszczają. Zaobserwowano, że przegrody w strzępkach nie zawsze sa ustawione pod katem $90^{\circ}$. Ustawienie ukośne jest dowodem asymetrycznego wydłużania się przeciwległych ścian, kiedy $z$ powodu przytwierdzenia do podłoża strzępka $z$ jednej strony została poddana rozciaganiu (CHRISTENSEN i współaut. 2008). Budowa strzępek jest silnie zwiazana $z$ wiekiem tkanek otaczajacych, czyli pozostaje pod wpływem gospodarza. W trawach o aktywnym wzroście strefy ekspansji strzepki maja prosta ultrastrukturę: sa wypełnione cytoplazma zawierajaca przede wszystkim rybosomy, mitochondria i jadra. W dojrzałych tkankach liści i/lub tkankach o grubych ścianach komórkowych cytoplazma wzbogaca się m.in. o krople lipidowe czy krystaloidy. Ponadto, strzepki w starszych liściach moga mieć grubsze ściany i przegrody, w porównaniu ze strzępkami w liściach młodych, co wskazuje, że synteza ścian nie ogranicza się, jak u innych gatunków, tylko do części wierzchołkowych, ale również zachodzi lokalnie (CHRISTENSEN i współaut. 2008).

Obserwacje Epichloë festucae w życicy trwałej (Lolium perenne L.) wykazały, że wzrost endofita $\mathrm{w}$ roślinie wymaga tworzenia odpowiednich struktur (BECKER i współaut. 2016). Strzępki znajdujące się bezpośrednio pod skórka (epiderma) wytwarzają expressoria, które umożliwiaja penetrację skórki liścia. Endofit nie uszkadza mechanicznie rośliny, lecz wymusza przebudowe blaszki środkowej epidermy, co zmniejsza jej grubość. Zjawisko to potwierdza brak doniesień o naruszeniu ścian komórkowych w skórce. W efekcie grzyb wydostaje się na powierzchnię i rozrasta się w obrębie pochwy i blaszki liściowej (BECKER i współaut. 2016). Epichloë festucae może rozrastać się powierzchniowo, kolonizując zarówno górna, jak i spodnią stronę blaszki liściowej. Przedstawione mechanizmy wzrostu wskazuja, że gatunek ten można określić jako endo- i epifityczny. 


\section{ODPORNOŚĆ SIECI}

Nieregularna sieć grzybni jest narażona na zmienne warunki środowiskowe, uszkodzenia mechaniczne i atak ze strony zwierząt. Dlatego tak ważna dla przeżycia jest odporność sieci, która naukowcy badaja dwoma technikami. Pierwsza, to badanie in silico, które polega na manipulacji według określonych reguł połaczeniami w sieciach cyfrowych. Druga, in vivo, dotyczy sprawdzania, jak ̇̇ywa sieć reaguje na kontakt $z$ różnymi bezkręgowcami. Przetrwanie sieci zależy od preferowanej przez dany gatunek wewnętrznej architektury i od zdolności do tworzenia nowych połączeń w rejonach uszkodzonych (HEATON i współaut. 2012). Co ciekawe, charakterystyczna dla sieci jest także selektywna utrata drobnych i osłabionych połaczeń (HEATON i współaut. 2012).

\section{ROLA PODSTAWOWA SIECI: ZDOBYCIE POKARMU}

Grzyby, jako organizmy cudzożywne (osmotroficzne), samodzielnie nie wytwarzaja niezbędnej do życia energii i materii, ale sa $\mathrm{w}$ pełni uzależnione od dostępności materiału (organicznego, żywego, martwego) $\mathrm{z}$ zewnattrz. Pokarm jest trawiony na zewnattrz ciała przez aktywne enzymy wydzielane do podłoża. Rozłożone zwiąki wnikają w postaci płynnej do organizmu grzyba, gdzie podlegaja kolejnym procesom. Grzyby, wykorzystując złożone związki organiczne, uwalniaja do środowiska zwiąki proste, które sa dostępne dla roślin i zwierząt. Ponadto, w odpowiedzi na pojawienie się nowych czynników w środowisku, moga produkować enzymy adaptacyjne, które zapewniaja im ogromną plastyczność w dostosowaniu się do zmiennych warunków (BUJAKIEWICZ i współaut. 2007). Bezpośredni pobór i rozpowszechnianie związków odżywczych poprzez dyfuzję sa wystarczajace do lokalnego odżywiania się w środowisku obfitym w zasoby (Ryc. 2). Jeśli w środowisku heteroge-

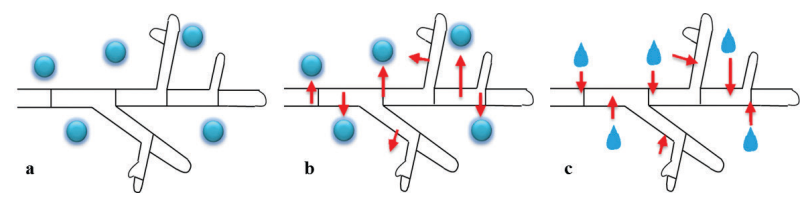

Ryc. 2. Wokół strzępek znajdują się związki pokarmowe (a), które sa trawione na zewnatrz przez wydzielane $z$ grzybni egzoenzymy (b). Rozłożone związki wnikaja do strzępek w postaci płynnej (c) i sa poddawane kolejnym procesom trawienia przez endoenzymy (rys. M. Dominiak za BUJAKIEWICZ i współaut. 2007). nicznym tylko fragment grzybni ma bezpośredni dostęp do źródła pokarmu, to pojawia się konieczność translokacji pobranych związków wzdłuż strzępek, czasem nawet na odległość kilku metrów. Translokacja związków odżywczych ma kluczowe znaczenie dla przetrwania grzybni, ponieważ strzępki rosnace $\mathrm{w}$ rejonie ubogim $\mathrm{w}$ pokarm sa wspierane przez te, które znajdują się w zasobniejszej części (Boswell i współaut. 2002). Słabo poznany mechanizm transportu na duże odległości próbowano wyjaśnić: udziałem białek motorycznych lub elementów kurczliwych, dyfuzja przez system wakuoli, istnieniem regulowanego gradientu osmotycznego oraz przeplywem masowym. W celu weryfikacji twierdzenia, że adwekcja (przepływ masowy) umożliwia translokację, badacze (HEATON i współaut. 2012) wstrzyknęli kropelki oleju do sieci i obserwowali ich ruch. Okazało się, że substancja przepływa przez strzępki $z$ ta sama szybkościa, $z$ jaka porusza się cytoplazma i organelle, więc nie występuja żadne specyficzne oddziaływania, np. zwiazane $\mathrm{z}$ białkami motorycznymi. Natomiast wstrzykiwanie znakowanego węgla czy fosforanów wskazało, że przepływ na określoną odległość $\mathrm{w}$ danym czasie nie może być wyjaśniany jedynie przez dyfuzję (HEAton i współaut. 2012). Przyspieszenie przepływu masowego jest efektem zmian ciśnienia wewnątrz strzępki (LEW 2011). Uważa się, że może być on dominującym mechanizmem transportu dalekobieżnego w sieciach o większej powierzchni.

\section{WYKORZYSTANIE SIECI GRZYBOWEJ PRZEZ ROŚLINY}

Od lat mykolodzy i fizjolodzy zajmuja się zwiazkami grzybów $z$ roślinami (np. TURNAU i współaut. 2001, BADRI i współaut. 2009, CHOFFnes i współaut. 2014, GORZELAK i współaut. 2015). Szeroko badane sa mikoryzy arbuskularne, obejmujące około $80 \%$ wszystkich znanych roślin naczyniowych (SMith i READ 2008). Grzyby z gromady Glomeromycota rozmnażaja się bezpłciowo przez spory, produkowane na zewnattrz korzenia (lub rzadziej w korze pierwotnej korzenia). Ze spory rozwijaja się strzępki grzybni, kolonizujące korzenie. Mikoryza umożliwia korzystanie przez grzyba $z$ węglowodanów rośliny oraz dostarczanie roślinie wody i pierwiastków, np. azotu, fosforu, wapnia czy potasu (GUCWA-PRZEPIÓRA 2012). Takie połaczenie grzybni $z$ korzeniami wymaga użycia przez organizmy odpowiednich cząstek sygnałowych. Rośliny wydzielaja strigolaktony należące do hormonów roślinnych, które sa sygnałem do zawiazania mikoryzy dla grzybów (BADRI i współaut. 2009). Natomiast 


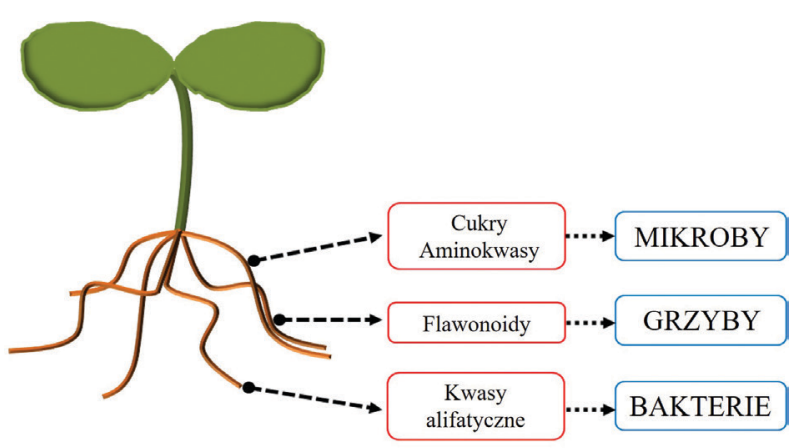

Ryc. 3. Schemat przedstawia komunikację pomiędzy roślinami a innymi organizmami.

Korzenie roślin wydzielają: (1) cukry i aminokwasy, które maja przyciagnać mikroby (chemotaksja), (2) flawonoidy inicjujące interakcje mikoryzowe $z$ grzybami, (3) kwasy alifatyczne (np. kwas jabłkowy) zwabiajace bakterie strefy korzeniowej wspomagające wzrost rośliny (BADRI i współaut. 2009, zmienione).

partner grzybowy, poprzez czynniki Myc, aktywuje zespoły genów roślinnych, które umożliwią mu rozwój grzybni i kolonizację korzeni rośliny (GUCWA-PRZEPIÓRA 2012). Cząsteczki sygnałowe roślin niosa nie tylko komunikaty dla grzybów, ale również dla innych organizmów (Ryc. 3) (BADRI i współaut. 2009). Dzięki wykorzystaniu sieci mikoryzowej rośliny komunikuja się pomiędzy sobą (GORZELAK i współaut. 2015), a nawet ostrzegaja przed niebezpieczeństwem (BABIKOVA i współaut. 2013). W przypadku ataku roślinożercy, rośliny wydzielaja lotne zwiazki, jak np. salicylan metylu, skutecznie odstraszające owady. Natomiast rośliny połaczone za pomoca wspólnej sieci mikoryzowej moga się "zbroić" jeszcze przed atakiem. Za pośrednictwem grzybów, otrzymują informacje o zaatakowanych sassiadach i zbliżajacym sie zagrożeniu, przez co mogą uruchomić wczesne reakcje obronne jeszcze przed atakiem roślinożercy (BABIKOVA i współaut. 2013). Dodatkowo, grzyby chronia roślinę przed patogenami chorobotwórczymi. Badania SonG i współaut. (2010) wykazały, że skolonizowane przez Glomus mossae korzenie pomidora chronia go przed Phytophthora parasitica (organizm wywołujący zarazę pomidora).

\section{WYKORZYSTANIE WIEDZY O SIECIACH GRZYBOWYCH PRZEZ CZEOWIEKA}

Rozrastające się mycelium tworzy skomplikowana sieć o niezawodnym działaniu. Dzięki pokrywaniu znacznych obszarów, grzybnie moga być stosowane przy zagospodarowaniu terenów dotkniętych problemem pustynnienia. Wchodzac w zwiąki mikoryzowe $z$ roślinami, strzępki łaccza je w samo- wystarczalne sieci. SprawiająO, że wzrasta ich powierzchnia wchłaniania wody, wydajniej wykorzystywane sa zasoby dostępne w ubogim, heterogenicznym środowisku. Dzięki temu znacznie wzrastaja szanse przeżycia młodych drzew, które w przyszłości wydadza obfite plony. Współpraca naukowców zajmujących się różnymi dziedzinami (matematyków, fizyków, bioinformatyków, biologów) dała możliwość usprawnienia sieci komunikacyjnych. Wzorcem dla tworzenia skutecznych układów sieciowych moga być grzybnie, które były tworzone przez naturę, bez wykorzystania znajomości reguł. Badania $z$ wykorzystaniem saprotroficznego grzyba korownicy aksamitnej (Phanerochaete velutina) pokazały, że do projektowania sieci transportowych można wykorzystać jego wzorzec wzrostu. Analiza rozrostu grzybni po 9, 18, 25, 31 i 39 dniach wykazała, że dzięki selektywnym stratom i wzmocnieniom połaczeń, mycelium dopasowuje się do otoczenia, by osiagnać najbardziej pożądane właściwości dla wysoce przepustowego transportu, przy zachowaniu odporności sieci (BEBBER i współaut. 2007). Reguły dotyczace tworzenia połączeń dodatkowych, które są niezbędne w przypadku uszkodzenia głównych ciagów komunikacyjnych u grzybów, mogą dać cenne wskazówki przy usprawnieniu systemów istniejacych obecnie oraz przy tworzeniu nowych.

Grzyby moga być wykorzystywane w produkcji przedmiotów codziennego użytku, takich jak: meble, naczynia, a nawet skórzane paski i torebki. MycoWorks jest jedna $z$ firm specjalizujacych sie w tzw. "mikotekturze”. Przedsiębiorstwo zyskało popularność dzięki stworzeniu skóry $Z$ mycelium lakownicy żółtawej (Ganoderma lucidum). Lakownica żółtawa znana jest ze swych właściwości leczniczych jako grzyb Reishi, a jej owocnik stanowi nadrzewna huba. W procesie produkcji skór, do strzępek dodawane są produkty uboczne pochodzenia roślinnego. Grzybnia wzrasta w plastikowych opakowaniach umieszczonych na regałach przez około dwa tygodnie. Pożądane właściwości (np. trwałość, struktura) uzyskuje się poprzez manipulację oświetleniem, wilgotnością i substancjami odżywczymi. Uzyskany materiał jest trwały i uniwersalny (więcej na stronie: http://www. mycoworks.com).

\section{WYKORZYSTANIE WŁAŚCIWOŚCI SIECI GRZYBOWYCH NA RZECZ SRODOWISKA PRZYRODNICZEGO}

Mycelium można wykorzystać $\mathrm{w}$ procesie rozkładu odpadów toksycznych w środowiskach zanieczyszczonych - mykoremediacji (SINGH 2006). Strzępki czerpia energię z roz- 
kładanych substancji, dzięki czemu szybko się rozrastaja. Wzmocniona, np. melanina, chitynowa ściana zapewnia im odporność na toksyny, zmienne zasolenie i ekstremalne temperatury. Dzięki wysokiej zdolności do wchłaniania, sieć idealnie spełnia swoja rolę w oczyszczaniu zdegradowanej gleby, po czym obumiera, a jej miejsce zajmuja inne organizmy.

Grzyby moga być $z$ powodzeniem wykorzystywane jako filtry biologiczne. Potwierdza to fakt, że w bieżacym roku w VTT Technical Research Centre of Finland odnotowano 80\% odzysk złota $z$ odpadów elektronicznych (więcej na stronie: www.vttresearch.com) poprzez akumulowanie go w grzybni. Pianki i opakowania wykonane $z$ tworzyw sztucznych (głównie polistyrenu) rozkładają się przez miliony lat. Amerykańska firma Ecovative Design, zajmujaca się tworzeniem biomateriałów przyjaznych dla środowiska, pracuje obecnie nad stworzeniem opakowań, które szybko ulegna biodegradacji, a budujace je zwiąki zostana $z$ powrotem właczone w zasoby ekosystemu. W tym celu odpady organiczne, np. łodygi i łuski kukurydzy, miesza się $z$ grzybnią i poddaje inkubacji przez około 48 godzin. Po zmieleniu, mieszanka jest umieszczana $\mathrm{w}$ formach na 3 dni, a nasteppnie wypalana $\mathrm{w}$ piecu. Uzyskany materiał jest obrabiany (cięcie, dopasowanie do pakowanych elementów). Rozkład zużytych opakowań trwa tylko kilka miesięcy. Być może grzybnię będzie można stosować w materiałach do izolacji pomieszczeń, jako materiał o wyższej odporności na ogień od obecnie wykorzystywanych pianek izolacyjnych, co zwiększy prawdopodobieństwo wydostania się, np. $z$ płonacego domu (więcej na stronie: www.ecovativedesign.com).

\section{ZAKOŃCZENIE}

Znaczenie grzybów w przyrodzie i gospodarce oddaja słowa wybitnego amerykańskiego biologa profesora Edwarda O. Wilsona: „(...) The world depends on fungi, because they are major players in the cycling of materials and energy around the world" (Świat zależy od grzybów, ponieważ to one spełniają rolę głównych graczy w obiegu materii i energii na całym świecie). Dodajac do tego dane liczbowe sugerujące, że około 90\% gatunków grzybów, a co za tym idzie ich właściwości, wciąz nie zostało odkrytych, możemy jedynie przypuszczać jak wielka rolę moga odgrywać.

\section{Streszczenie}

Grzyby to organizmy występujace we wszystkich strefach klimatycznych, zasiedlające głównie lądy. Dzięki dopasowującym się do warunków środowiska mechanizmom wzrostu, tworzą podziemne sieci, zajmujące znaczną powierzchnię. W obrębie sieci rosnącej w heterogenicznym środowisku zachodzi transport zwiąków odżywczych przez translokację długodystansową. Translokacja ma kluczowe znaczenie dla przetrwania grzybni, ponieważ strzępki rosnace w rejonie ubogim w pokarm są wspierane przez znajdujące się w części zasobniejszej. Grzyby moga wchodzić w interakcje $z$ innymi organizmami. Wykorzystując czynniki Myc aktywuja zespoły genów roślinnych, co umożliwia rozwój grzybni, kolonizację korzeni rośliny, a w efekcie prowadzi do zawiazania mikoryzy. Sieci mikoryzowe wykorzystywane sa przez rośliny do komunikacji i ostrzegania się przed niebezpieczeństwem. Natomiast ludzie wykorzystują właściwości sieci grzybowych m.in. do planowania przebiegu sieci komunikacyjnych, mykoremediacji czy produkcji opakowań biodegradowalnych. Przyjmując, że na świecie występuje ok 1,5 miliona gatunków grzybów, $z$ czego znanych jest jedynie ok. 10\%, możemy przypuszczać, jak wiele ich niezwykłych właściwości pozostaje do odkrycia.

\section{LITERATURA}

Babkova Z., Gilbert L., BRUCE T. J. A., BirketT M., Caulfield J. C., Woodcock C., Pickett J. A., JoHnson D., 2013. Underground signals carried through common mycelial networks warn neighbouring plants of aphid attack. Ecol. Lett. 16, 835-843.

BADRI D. V., WEIR T. L., VAN DER LELIE D., VIVANCO J. M., 2009. Rhizosphere chemical dialogues: Plant-microbe interactions. Curr. Opin. Biotechnol. 20, 642-650.

BebBeR D. P., Hynes J., DARRAH P. R., BODDY L., FICKER M. D., 2007. Biological solutions to transport network design. Proc. Royal Soc. B 274, 2307-2315.

BECKER M., BECKER Y., GREen K., SCOTT B., 2016. The endophytic symbiont Epichloë festucae establishes an epiphyllous net on the surface of Lolium perenne leaves by development of an expressorium, an appressorium-like leaf exit structure. New Phytol. 211, 240-254.

Boswell G. P., Jacobs H., Davidson F. A., GadD G. M., RitZ K., 2002. Functional consequences of nutrient translocation in mycelial fungi. J. Theor. Biol. 217, 459-477.

Bujakiewicz A., Lisiewska M., NiTA J., 2007. Mikologia. Przewodnik do ćwiczen terenowych $i$ laboratoryjnych. Bogucki, Wydawnictwo Naukowe, Poznań.

Choffnes E. R., Olsen L. A., MACK A., 2014. Microbial ecology in states of health and disease: workshop summary. The National Academies Press, Washington.

CHRISTENSEN M. J., BENNETT R. J., ANSARI H. A., KOGA H., JOHNSON R. D., BRYAN G. T., SimPSON W. R., KOOlaARD J. P., NiCKLESS E. M., VOISEY C. R., 2008. Epichloë endophytes grow by intercalary hyphal extension in elongating grass leaves. Fungal Genet. Biol. 45, 84-93.

DE KROON H., VAN GROENENDAEL J., 1997. The ecology and evolution of clonal plants. Backhuys Publishers, Leiden.

DOMINIAK M., PISZCZAEKA P., LEMBICZ M., 2014. Roślinny internet. Wiedza i Życie 48, 36-37.

GorzelaK M. A., ASAY A. K., PICKLES B. J., SiMARD S. W., 2015. Inter-plant communication through mycorrhizal networks mediates complex adaptive behaviour in plant communities. AoB Plants 7, doi: 10.1093/aobpla/plv050.

GUCWA-PRZEPIÓRA E., 2012. Udział mikoryzy arbuskularnej $w$ procesach fitoremediacji - mikoryzoremediacja. Wiad. Botan. 56, 5-19. 
HAWKSWORTH D. L., 1991. The fungal dimension of biodiversity: magnitude, significance, and conservation. Mycol. Res. 95, 641-655.

HEATON L., OBara B., GRAU V., JONES N., NAKAGAKI T., BODDY L., FRICKER M. D., 2012. Analysis of fungal networks. Fungal Biol. Rev. 26, 12-29.

LEW R. R., 2011. How does a hypha grow? The biophysics of pressurized growth in fungi. Nat. Rev. Microbiol. 9, 509-518.

Moore D., RoBSON G. D., TRINCI A. P. J., 2011. 21st Century guidebook to fungi. Cambridge University Press, New York.

RUIZ HERRERA J., 1991. Fungal cell wall: structure, synthesis and assembly. CRC Press, Florida.

SingH H., 2006. Mycoremediation: Fungal bioremediation. John Wiley \& Sons, New Jersey.

SMith S. E., READ D. J., 2008. Mycorrhizal sym biosis. Academic Press, London.

SONG Y. Y., ZENG R. S., XU J. F., LI J., SHEN X., YIHDEGO W. G., 2010. Interplant communication of tomato plants through underground common mycorrhizal networks. PLoS One 5, e13324.

STAMETS P., 2005. Mycelium Running. How mushrooms can help save the world? Teen Speed Press, Berkley.

Stuefer J. F., Gómez S., VAN MöLKen T., 2004. Clonal integration beyond resource sharing: implications for defence signalling and disease transmission in clonal plant networks. Evol. Ecol. 18, 647-667.

Turnau K., Berger A., Lowe A., Hampp R., ChaLOT M., P. Dizengremel P., KotTKe I., 2001. Carbon dioxide concentration and nitrogen input interact with the formation of glycogen and of $\mathrm{N}$-containing vacuolar bodies in Amanita muscaria-Picea abies mycorrhizas. Tree Physiol. 21, 93-99.

WHITNEY K. D., 1989. Systems of biomineralization in the fungi. [W:] Origin, evolution, and modern aspects of biomineralization in plants and animals. CRICK R. E. (red.). Springer Science+Business Media, New York, 433-441.

KOSMOS Vol. 67, 2, 313-318, 2018

MARTyna DominiaK, MARLENA LEMBicZ

Department of Plant Taxonomy, Faculty of Biology, Adam Mickiewicz University in Poznań, Umultowska 89, 61-614 Poznań, E-mail: martyna.dominiak@amu.edu.pl

FUNGAL NETWORKS - STRUCTURE, FUNCTION AND USE BY HUMANS

Summary

Fungi are mostly terrestrial organisms occurring in all climatic zones. Thanks to the growth mechanisms that are adaptable to environmental conditions, they form underground networks covering large areas. Within a network that grows in heterogenic environment, nutrients are allocated through a long-distance translocation. Translocation is of a key importance for mycelium survival, because hyphae growing in a nutrient-poor place are supported by hyphae from a nutrient-rich area. Fungi may also enter into interactions with other organisms. Using Myc factors, they activate plant gene complexes, which enables the development of mycelium and colonization of plant roots leading to the development of mycorrhiza. Mycorrhizal networks are used by plants to communicate and warn each other of a danger. In turn, humans use the characteristics of fungal networks, among others, to design the flow of communication systems, for myco-remediation and production of biodegradable packing materials. Assuming that about $1.5 \mathrm{mln}$ of fungal species occur in the world, out of which only some $10 \%$ are known, we can only presume how many unusual properties of fungi remain still undiscovered.

Key words: fungal network, long-distance translocation, mycorrhiza 